Utah State University

DigitalCommons@USU

$5-17-2021$

\title{
Episodic Occurrence of Favourable Weather Constrains Recovery of a Cold Desert Shrubland After Fire
}

\author{
Alexandra K. Urza \\ USDA Forest Service, alexandra.urza@usda.gov \\ Peter J. Weisberg \\ University of Nevada \\ David Board \\ USDA Forest Service \\ Jeanne C. Chambers \\ USDA Forest Service \\ Stanley G. Kitchen \\ USDA Forest Service \\ Bruce A. Roundy \\ Brigham Young University
}

Follow this and additional works at: https://digitalcommons.usu.edu/sagestep_articles

\section{Recommended Citation}

Urza, AK, Weisberg, PJ, Board, D, Chambers, JC, Kitchen, SG, Roundy, BA. Episodic occurrence of favourable weather constrains recovery of a cold desert shrubland after fire. J Appl Ecol. 2021; 58: 17761789. https://doi.org/10.1111/1365-2664.13911

This Article is brought to you for free and open access by the Publications at DigitalCommons@USU. It has been accepted for inclusion in Articles by an authorized administrator of DigitalCommons@USU. For more information, please contact digitalcommons@usu.edu.

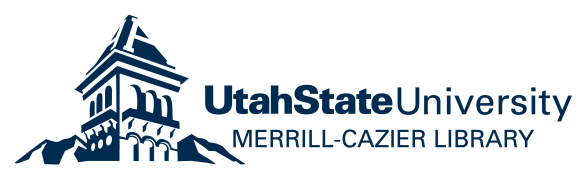




\title{
Episodic occurrence of favourable weather constrains recovery of a cold desert shrubland after fire
}

\author{
Alexandra K. Urza, ${ }^{1,2}$ | Peter J. Weisberg ${ }^{2,3}$ | David Board $^{1}$ (D) | Jeanne C. Chambers ${ }^{1}$ (D) | \\ Stanley G. Kitchen ${ }^{4}$ (D) | Bruce A. Roundy ${ }^{5}$ (D)
}

${ }^{1}$ USDA Forest Service, Rocky Mountain Research Station, Reno, NV, USA

${ }^{2}$ Ecology, Evolution, and Conservation Biology Graduate Program, University of Nevada, Reno, NV, USA

${ }^{3}$ Department of Natural Resources and Environmental Science, University of Nevada, Reno, NV, USA

${ }^{4}$ USDA Forest Service, Rocky Mountain Research Station, Provo, UT, USA

${ }^{5}$ Department of Plant and Wildlife Sciences, Brigham Young University, Provo, UT, USA

\section{Correspondence}

Alexandra K. Urza

Email: alexandra.urza@usda.gov

Funding information

US Joint Fire Science Program, Grant/Award Number: 16-2-01-27; USDA Forest Service, Rocky Mountain Research Station

Handling Editor: Don Driscoll

\section{Abstract}

1. Key to the long-term resilience of dryland ecosystems is the recovery of foundation plant species following disturbance. In ecosystems with high interannual weather variability, understanding the influence of short-term environmental conditions on establishment of foundation species is essential for identifying vulnerable landscapes and developing restoration strategies. We asked how annual environmental conditions affect post-fire establishment of Artemisia tridentata, a shrub species that dominates landscapes across much of the western United States, and evaluated the influence of episodic establishment on population recovery.

2. We collected $A$. tridentata stem samples from 33 plots in 12 prescribed fire sites that burned 8-11 years before sampling. We determined individual establishment years using annual growth rings. We measured seasonal soil environmental conditions at the study sites and asked if these conditions predicted annual establishment density. We then evaluated whether establishment patterns could be predicted by site-level climate or dominant subspecies. Finally, we tested the effect of the magnitude and frequency of post-fire establishment episodes on longterm population recovery.

3. Annual post-fire recruitment of $A$. tridentata was driven by the episodic availability of spring soil moisture. Annual establishment was highest with wetter spring soils (relative influence $[\mathrm{RI}]=19.4 \%$ ) and later seasonal dry-down $(\mathrm{RI}=11.8 \%)$ in the year of establishment. Establishment density declined greatly 4 to 5 years after fire $(\mathrm{RI}=17.1 \%)$. Post-fire establishment patterns were poorly predicted by site-level mean climate (marginal $R^{2} \leq 0.18$ ) and dominant subspecies (marginal $R^{2} \leq 0.43$ ).

4. Population recovery reflected the magnitude, but not the frequency, of early post-fire establishment pulses. Post-fire A. tridentata density and cover (measured 8-11 years after fire) were more strongly related to the magnitude of the largest establishment pulse than to establishment frequency, suggesting that population recovery may occur with a single favourable establishment year.

5. Synthesis and applications. This study demonstrates the importance of episodic periods of favourable weather for long-term plant population recovery following 
disturbance. Management strategies that increase opportunities for seed availability to coincide with favourable weather conditions, such as retaining unburned patches or repeated seeding treatments, can improve restoration outcomes in high-priority areas.

\section{KEYWORDS}

annual weather conditions, big sagebrush, ecological restoration, favourable weather, plant establishment, post-fire recovery, prescribed fire, resource pulses

\section{1 | INTRODUCTION}

Altered disturbance regimes, shifting climate and non-native plant invasions are resulting in the transformation of dryland ecosystems around the globe (Maestre et al., 2016). Key to long-term resilience of dryland ecosystems is recovery of foundation plant species following disturbance. Foundation plant species typically dominate an ecosystem's structure and influence ecosystem processes and the distribution and abundance of a wide range of community members, and thus play a disproportionate role in ecosystem recovery (Brown et al., 2001). Spatial differences in mean environmental conditions, such as along climatic gradients, are important predictors of recovery potential (Arnan et al., 2007; Shryock et al., 2015). In many dryland environments, however, year-to-year fluctuations in weather can exceed spatial differences among climate zones (Loik et al., 2004) and exert strong effects on biological processes (Schwinning \& Sala, 2004). In ecosystems with high interannual weather variability, a greater understanding of the influence of short-term environmental conditions on the rate and trajectory of foundation species recovery after disturbance can be used to inform restoration strategies by identifying landscapes that are vulnerable to disturbance and climate change.

Globally, the invasion of non-native plants has altered fire regimes and, in some cases, initiated grass-fire cycles resulting in the loss of foundation species (Brooks et al., 2004). Understanding foundation species' responses to fire is necessary for the conservation of native habitats in the context of altered fire regimes. Resource pulses are a critical driver of ecosystem dynamics in drylands, where the amount and timing of precipitation vary greatly from year to year (Schwinning \& Sala, 2004). Dryland ecosystems are typically resource-limited, and plant population processesincluding seed production, establishment and growth-often fluctuate in response to resource pulses driven by interannual weather conditions (Petrie et al., 2017; Redmond et al., 2012, 2017). Overall shifts towards warmer and drier conditions in the future are expected to impact population dynamics of dryland plant species (e.g. Miranda et al., 2009; Renwick et al., 2018), yet interannual variability in weather can create complex trends despite linear shifts in mean conditions (de Elía et al., 2013; Malanson et al., 2017). Continuous multi-year observations of plant demographic responses can provide powerful insights into how populations and communities may respond to the interacting effects of climate and disturbance regime changes (Kleinhesselink \& Adler, 2018).

In cold deserts of the western United States, Artemisia tridentata Nutt. (big sagebrush) is a foundation shrub species that characterizes multiple ecological types across tens of millions of ha (Davies et al., 2011). The interacting effects of increasing wildfire, annual grass invasions and land use have led to widespread loss of sagebrush ecosystems in recent decades (Fusco et al., 2019). Fire often facilitates invasion of non-native annual grasses such as Bromus tectorum (cheatgrass), leading to shortened grass-fire cycles and resulting in transformation of native ecosystems to annual grass-dominated landscapes (Bradley et al., 2018). Following fire, a central management objective is reestablishment of sagebrush species, which are critical habitat elements for Greater sage-grouse and other species of conservation concern (Coates et al., 2016). However, most sagebrush taxa, including the widespread species $A$. tridentata, are not adapted to fire and do not resprout. Post-fire recovery must occur through seeds, which have short-distance dispersal and very limited (1-2 years) viability in the soil seed bank (Wijayratne \& Pyke, 2012). To promote post-fire $A$. tridentata recovery in large burns where seed dispersal is limited, land managers have invested heavily in seeding treatments (Pilliod et al., 2017). However, post-fire seeding efforts are often unsuccessful at increasing $A$. tridentata cover (Arkle et al., 2014; Knutson et al., 2014), indicating that seed availability alone does not ensure recovery.

As for many dryland plants, A. tridentata recruitment is driven largely by soil water availability (Schlaepfer et al., 2014). Cold deserts of the western U.S. have a winter-dominated precipitation regime, and soil moisture typically peaks in late winter before gradually declining (Shriver et al., 2018). Long-term regeneration success of $A$. tridentata in large burned areas is strongly related to spring soil moisture in the first year after fire (Nelson et al., 2014) or after post-fire seeding (Shriver et al., 2018), indicating that successful establishment requires favourable weather conditions coincident with the short period of seed viability. Wet-thermal models show that germination of dryland species relies on accumulation of warm and wet conditions in near-surface soils (Cline, Roundy, \& Christensen, 2018). Near-surface soils tend to be much warmer in burned sites than in unburned sites, allowing germination requirements to be met more quickly during wet spring periods, yet hotter and drier conditions in late spring can increase seedling mortality risk (Cline, Roundy, Hardegree, et al., 2018). Freezethaw cycles may also constrain survival of early-germinating seedlings 
(Roundy \& Madsen, 2016). Recruitment may be further limited by competition from other plants (Chambers et al., 2017), resulting in a short post-fire window for establishment before resources are redistributed among plants recovering from or colonizing after fire (Ziegenhagen \& Miller, 2009). These drivers of establishment vary annually, and although climate projections indicate reduced regeneration in hotter and drier areas (Schlaepfer et al., 2015), it is unlikely that establishment patterns can be accurately predicted from mean climate variables (Miranda et al., 2009).

The long-term population implications of short-term regeneration success are critically important for restoration but poorly understood. In ecosystems with extremely infrequent favourable conditions for recruitment, population recovery may be driven by a single establishment event, indicating pulse-driven population dynamics (Chesson et al., 2004). However, multiple establishment events have a cumulative effect on population size (Wiegand et al., 2004), and more frequent establishment events may result in larger populations, buffering population losses from seedling mortality by spreading the risk across multiple years (Shriver et al., 2019). Dendroecological studies reconstruct past regeneration events, facilitating insight into the dynamics that have produced extant communities and providing opportunities for connecting short-term regeneration events and long-term population responses.

Here, we investigated how seasonal environmental conditions affect annual $A$. tridentata establishment and evaluated the influence of episodic establishment patterns on post-fire population recovery. We combined dendroecological methods, soil environmental data and vegetation measurements from prescribed fires spanning broad environmental gradients to ask: (a) How does post-fire A. tridentata establishment respond to seasonal environmental conditions and time since fire? We hypothesized that establishment would be greatest in years with high spring soil water availability and more likely immediately after fire, before competition with other plants and seedbank depletion inhibits establishment. (b) Can temporal patterns of $A$. tridentata establishment be predicted based on mean climate? We hypothesized that drier sites would have more variable establishment patterns and smaller establishment peaks, reflecting a lower likelihood of favourable conditions for recruitment. (c) How is post-fire A. tridentata population recovery influenced by temporal patterns of post-fire establishment? We hypothesized that cover and density would be highest in sites with larger establishment peaks and with more frequent establishment events, but that the influence of establishment frequency would be strongest. Identifying the drivers of post-fire establishment and influences on population recovery will help managers identify vulnerable portions of the landscape and prioritize interventions.

\section{2 | MATERIALS AND METHODS}

\section{1 | Study site locations}

Our study took place in 12 prescribed burn sites across the Intermountain West of the United States (Figure 1). Study sites were

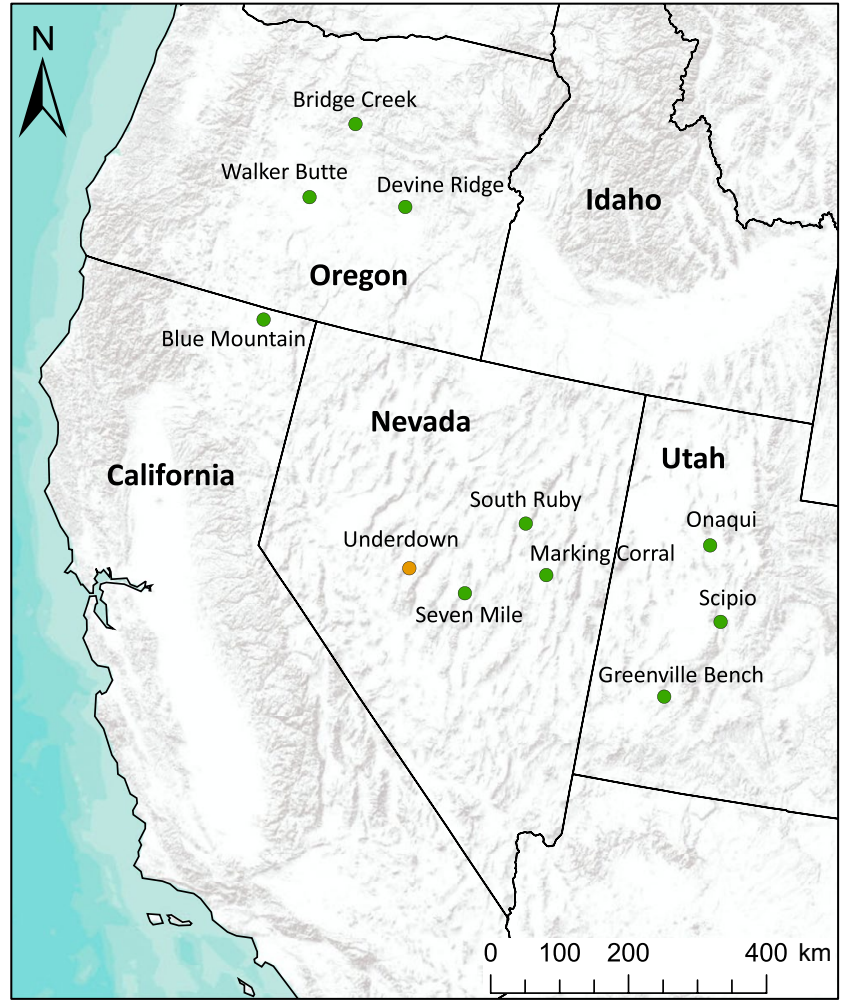

FIGURE 1 Map of the study sites in the Intermountain West, USA. Green circles indicate sites that are part of the SageSTEP network. The orange circle indicates the location of the Underdown Canyon Demonstration Area (two sites)

part of two experimental networks in ecosystems co-dominated by pinyon-juniper (Pinus and Juniperus species) woodlands and A. tridentata shrublands. Underdown Canyon (two sites) is a Demonstration Area established to study ecological effects of prescribed fire across a local elevational gradient (Urza et al., 2017, 2019). The Sagebrush Steppe Treatment Evaluation Project (SageSTEP; 10 sites) is a longterm regional-scale study examining effects of multiple fuel treatments (Mclver \& Brunson, 2014).

Sites were distributed across a broad geographical area encompassing a range of edaphic and climatic gradients and contained three subspecies of $A$. tridentata (Table 1). Prescribed fire treatments were implemented between 2004 and 2009 using a 'stagger-start' design that increases variability in post-treatment weather and thus reduces potential for restricted inferences (Loughin, 2006). Study sites were fenced to prevent livestock grazing and no post-fire seeding or planting treatments were implemented. Post-treatment weather across the region was variable, characterized by longer periods of drought punctuated by infrequent cool, wet years (Roundy et al., 2014, 2020).

\subsection{Field methods}

We collected data in 2015 (Underdown) and 2017 (SageSTEP) on post-fire A. tridentata density and cover and obtained stem samples 
TAB LE 1 Characteristics of the 12 study sites, including year burned, the Artemisia tridentata subspecies present at the site, and environmental attributes

\begin{tabular}{|c|c|c|c|c|c|c|}
\hline Site & $\begin{array}{l}\text { Year } \\
\text { burned }\end{array}$ & $\begin{array}{l}\text { Artemisia } \\
\text { tridentata } \\
\text { subspecies }\end{array}$ & $\begin{array}{l}\text { Elevation } \\
(\mathrm{m})^{\mathrm{a}}\end{array}$ & $\begin{array}{l}\text { Annual precipitation } \\
(\mathrm{mm})^{\mathrm{b}}\end{array}$ & $\begin{array}{l}\text { Mean annual } \\
\text { temperature }\left({ }^{\circ} \mathrm{C}\right)^{\mathrm{b}}\end{array}$ & $\begin{array}{l}\text { Annual climatic water } \\
\text { deficit }(\mathrm{mm})^{c}\end{array}$ \\
\hline \multicolumn{7}{|l|}{ SageSTEP network } \\
\hline $\begin{array}{l}\text { Blue Mountain, } \\
\text { CA (BM) }\end{array}$ & 2007 & vaseyana & 1,494 & $454 \pm 21.2$ & $7.6 \pm 0.11$ & $218 \pm 8.2$ \\
\hline $\begin{array}{l}\text { Bridge Creek, OR } \\
\text { (BC) }\end{array}$ & 2006 & tridentata & 909 & $306 \pm 13.5$ & $9.8 \pm 0.13$ & $373 \pm 8.9$ \\
\hline $\begin{array}{l}\text { Devine Ridge, OR } \\
\text { (DR) }\end{array}$ & 2007 & vaseyana & 1,508 & $373 \pm 15.1$ & $6.0 \pm 0.16$ & $237 \pm 7.2$ \\
\hline $\begin{array}{l}\text { Greenville Bench, } \\
\text { UT (GR) }\end{array}$ & 2007 & wyomingensis & 1,851 & $330 \pm 13.3$ & $9.5 \pm 0.11$ & $326 \pm 7.8$ \\
\hline Scipio, UT (SC) & 2007 & wyomingensis & 1,742 & $394 \pm 13.5$ & $9.7 \pm 0.13$ & $373 \pm 8.3$ \\
\hline $\begin{array}{l}\text { Seven Mile, NV } \\
\text { (SV) }\end{array}$ & 2007 & wyomingensis & 2,256 & $265 \pm 11.6$ & $7.0 \pm 0.12$ & $316 \pm 8.3$ \\
\hline $\begin{array}{l}\text { South Ruby, NV } \\
\text { (SR) }\end{array}$ & 2008 & wyomingensis & 2,011 & $317 \pm 14.4$ & $7.7 \pm 0.12$ & $321 \pm 7.4$ \\
\hline $\begin{array}{l}\text { Walker Butte, OR } \\
\text { (WB) }\end{array}$ & 2006 & vaseyana & 1,416 & $261 \pm 12.9$ & $6.6 \pm 0.12$ & $287 \pm 7.7$ \\
\hline \multicolumn{7}{|c|}{ Underdown Canyon Demonstration Area } \\
\hline $\begin{array}{l}\text { Underdown Mid, } \\
\text { NV (NM) }\end{array}$ & 2004 & vaseyana & 2,170 & $333 \pm 17.8$ & $7.4 \pm 0.12$ & $228 \pm 7.4$ \\
\hline
\end{tabular}

${ }^{a}$ Mean elevation of sampling plots.

b30-year record from 1981 to 2010 (PRISM Climate Group, 2016).

c30-year record from 1981 to 2010 (Dilts et al., 2015).

for determining establishment dates. We randomly located sampling plots within prescribed burn perimeters. Three sampling plots were established at each site, except Scipio and Bridge Creek, where smaller burn areas restricted sampling to one and two plots respectively. Our final sampling design included 33 plots across 12 sites.

We measured shrub cover by species using the canopy gap intercept method (Herrick et al., 2017). We recorded shrub canopies along 6- $\mathrm{m}$ transects extending radially in 8 cardinal and ordinal directions from plot centre. Artemisia tridentata stem samples were then collected from variable-radius plots. The plot radius was based on a target sample size of five samples for each year between burning and sampling (number of years between burning and sampling varied among sites). Collection plots were expanded radially until the target sample size was met, cutting all $A$. tridentata individuals below the root crown for a complete demographic profile. If the target sample size was not met within a 6-m radius, up to two additional plots were established at nearby randomized locations, and all samples and measurements were pooled within plot clusters.

\section{3 | Laboratory methods}

A total of 2,004 A. tridentata stem samples were collected. Samples were cross-sectioned with a band saw to expose the pith at the junction of root crown and stem. Stem samples were then processed using standard dendrochronological techniques (Stokes $\&$ Smiley, 1968). We used annual ring counts to determine establishment year because the young age of the samples precluded cross-dating and minimized chances of drought-induced missing rings. Annual growth rings were counted under a stereomicroscope by two individuals, and samples for which the independent ring counts disagreed were re-examined. For samples that did not include the pith $(n=25)$, we overlaid concentric circles to estimate the number of missing years (Nelson et al., 2014). For analyses of post-fire establishment, we removed samples that established prior to the year of burning $(n=415)$ or in the year of sampling $(n=83)$. In total, we used 1,506 A. tridentata individuals in postfire analyses. 


\subsection{Soil environmental data}

Soil temperature and water availability were measured in each burned site. Soil temperature was recorded using thermocouples and soil water matric potential was measured using gypsum blocks, at multiple soil depths: $1-3,13-15$ and $28-30 \mathrm{~cm}$. Data microloggers were programmed to read sensors every $60 \mathrm{~s}$ and store hourly averages. Sites were instrumented immediately after burn treatments, and with the exception of small data gaps resulting from sensor malfunctions, data on soil temperature and water availability were collected through the year of sampling. Hourly measurements were used to calculate a suite of seasonal variables associated with plant growth and cover (Roundy et al., 2014). Further details on soil environmental data are in Roundy et al. (2018) and Chambers et al. (2007).

\section{5 | Statistical analyses}

\subsection{1 | Drivers of annual post-fire establishment}

We modelled annual A. tridentata establishment density as a function of time since fire and soil environmental conditions. Annual establishment density represents the number of $A$. tridentata individuals that established in each calendar year in each plot, scaled to density $\left(\mathrm{ha}^{-1}\right)$. We used generalized boosted regression trees because they were appropriate for modelling nonlinear relationships in our dataset (Elith et al., 2008) and have previously been used to model post-fire seedling recruitment (e.g. Christopoulou et al., 2014; Johnstone et al., 2010). We focused on soil environmental predictors that represent water availability during spring and early summer (Table 2), which are critical seasons for $A$. tridentata recruitment
(Shriver et al., 2018). As soil measurements in different depths were highly correlated, we used measurements from a single depth to reduce potential effects of collinearity on the interpretation of individual variable effects. We used near-surface soil measurements (1-3-cm depth), which were more strongly correlated with establishment than deeper soil measurements and were consistent with prior work on germination and early seedling survival (e.g. Cline, Roundy, Hardegree, et al., 2018).

The model was fit in $\mathrm{R}$ version 3.5.2 (R Core Team, 2018), using the gbm.step function in the DISMo package (Hijmans et al., 2017) and the $g b m$ function in the GBM package (Greenwell et al., 2019). The model was defined with 10 -fold cross-validation, bag fraction of 0.5 , complexity of 3 , and learning rate of 0.003 to achieve the recommended 1,000 trees per model (Elith et al., 2008). Effects were interpreted by examining relative influence and plotting partial dependencies for individual predictor variables.

\subsection{2 | Temporal patterns of post-fire establishment across regional climatic gradients}

For each plot $(N=33)$, we used annual establishment density (plants/ ha) from the first 8 post-fire years to calculate metrics of temporal patterns of post-fire A. tridentata establishment. Median establishment represented a typical post-fire year, maximum establishment represented the largest establishment peak, CV of establishment represented interannual variation, and the proportion of years with establishment represented the frequency of establishment events. Median, maximum and CV were $\log _{10}$-transformed prior to analysis.

Artemisia tridentata subspecies are strongly stratified by climate, precluding the presence of subspecies and climate as explanatory variables in the same models. Thus, we used linear mixed effects

TABLE 2 List of predictor variables used in the boosted regression tree model predicting annual Artemisia tridentata establishment. Variables represent conditions in the year of establishment, except for those named 'year +1 ', which represent conditions in the year following establishment. Spring = March through June; Summer = July through August; Winter = December through February, assigned to the subsequent calendar year

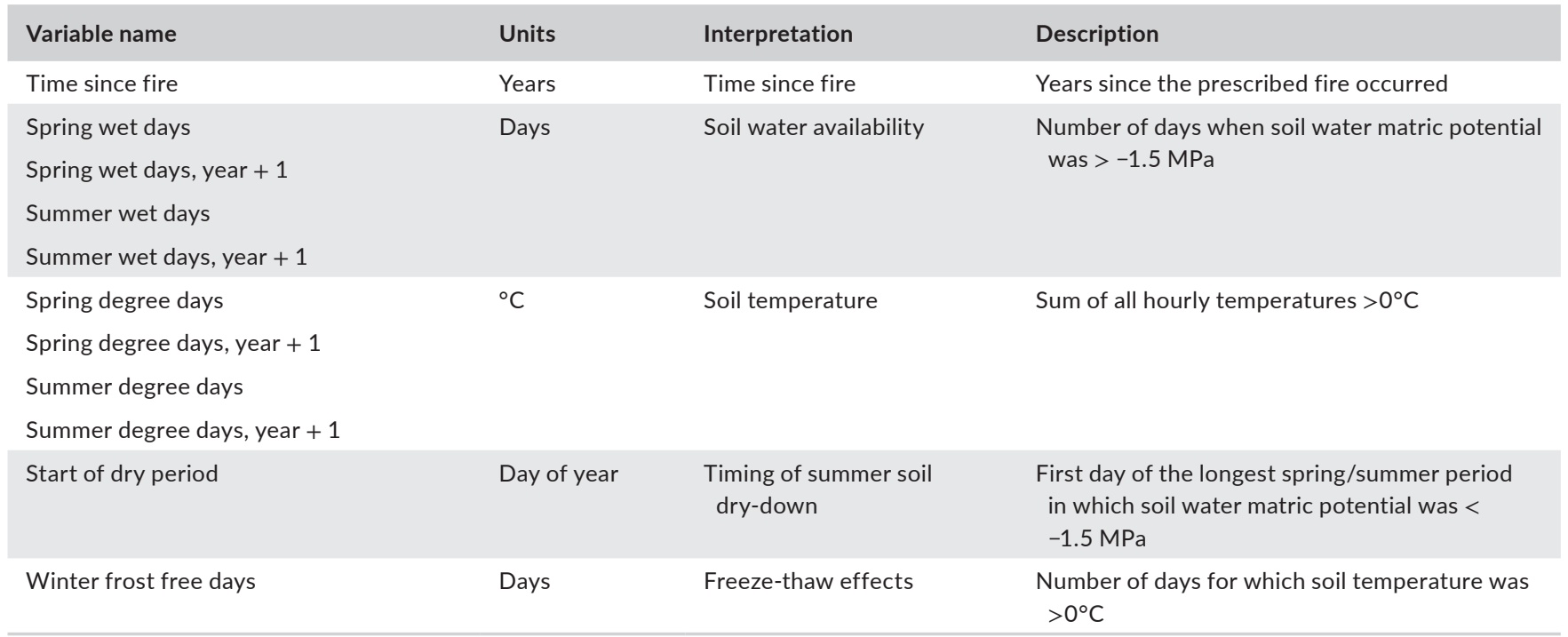


models to compare two alternative sets of predictors: a suite of climatic normals (climate model) or dominant subspecies of $A$. tridentata (subspecies model). In climate models, we predicted each establishment metric as a function of site-level climate variables (1981-2010 normals): annual precipitation, mean annual temperature and spring climatic water deficit. Annual precipitation and temperature were from 30-year-normal gridded PRISM climate data (PRISM Climate Group, 2016). Spring climatic water deficit (March-June; from Dilts et al., 2015) was calculated using a Thornthwaite water balance model (Lutz et al., 2010) that incorporates monthly temperature and precipitation, elevation and soil water storage. Pairwise correlations (Pearson's $r$ ) between climatic predictor variables were $<0.61$. In subspecies models, we predicted each establishment metric as a function of the dominant $A$. tridentata subspecies (factor with three levels: A.t. tridentata [ $n=2]$, A.t. wyomingensis [ $n=16]$, and A.t. vaseyana $[n=15])$. For both climate and subspecies models, the density of residual pre-fire $A$. tridentata (i.e. individuals that established before the fire; $\mathrm{ha}^{-1}$ ) was included as a predictor variable to represent effects on seed availability and species interactions. Site was included as a random intercept to account for spatial clustering of plot observations.

Models were built in R package LME4 (Bates et al., 2015). We scaled climatic predictor variables (z-score) and reported standardized parameter coefficient estimates. 95\% confidence intervals were estimated for all fixed effects using the confint function with bootstrapping in LME4. Marginal and conditional $R^{2}$ values were calculated using the r.squaredGLMM function in the MuMIN package (Barton, 2015).

\subsection{3 | Importance of temporal patterns of post-fire establishment for long-term population recovery}

To evaluate importance of temporal patterns of post-fire establishment on population recovery, we modelled total post-fire A. tridentata density and cover as a function of post-fire establishment metrics, controlling for time since fire and dominant subspecies. Post-fire A. tridentata density is the total number of $A$. tridentata individuals that established after burning in each plot, scaled to density $\left(\mathrm{ha}^{-1}\right)$, and represents the size of the post-fire population. Cover is the percent of the plot area covered by A. tridentata canopy cover, and represents the availability of sagebrush habitat. The correlation (Pearson's $r$ ) between post-fire density and cover was 0.49 . We used linear mixed effects models to predict post-fire density (ha ${ }^{-1}$ ) and cover (\%; $\log _{10}$-transformed). Fixed effects included metrics representing the abundance (median and maximum) and frequency (proportion of establishment years) of post-fire establishment, calculated for each plot as described above. Fixed effects also included time since fire (ranging from 8 to 11 years), residual A. tridentata density, and dominant subspecies. Pairwise correlations (Pearson's $r$ ) between continuous fixed effects were $<0.6$. Site was included as a random intercept to account for spatial clustering of plot observations. Models and outputs were produced as described in the previous section.

\section{3 | RESULTS}

\section{1 | Drivers of annual post-fire establishment}

Eighty percent of dated $A$. tridentata individuals established after the prescribed fires. However, all 12 sites, and 28 of 33 sampling plots, contained residual individuals that established pre-fire. Post-fire $A$. tridentata establishment was highly episodic for all sites, with nonuniform patterns of establishment density across post-fire years (see Figure S1 in Supporting Information). Considering all possible establishment years across sampling plots, $50 \%$ of establishment occurred in only $11 \%$ of possible plot-year combinations, and $34 \%$ of possible plot-year combinations had no observed establishment.

Model results (cross-validated $A \cup C=0.917$ ) suggest that $A$. tridentata establishment was primarily driven by spring soil water availability in the year of establishment. Three of the four highest-ranked predictor variables represented various measures of spring soil moisture. Establishment density was greatest in years with wetter spring soils, represented by a higher number of spring wet days (Figure 2a). Similarly, establishment density was greatest in years with a later soil dry-down, indicated by the start of the spring/summer dry period (Figure 2c), and with cooler springs, indicated by lower spring degree days (Figure $2 \mathrm{~d}$ ). Time since fire was the variable with the second-highest relative influence. Establishment density was greatest immediately after fire, declining in a threshold-like manner 4 to 5 years after fire (Figure 2b). Summer conditions, winter frost-free days, and all variables from the year following establishment were weak predictors (Figure $2 \mathrm{e}-\mathrm{j}$ ).

\section{2 | Temporal patterns of post-fire establishment across regional climatic gradients}

Temporal patterns of $A$. tridentata establishment in the 8 years following fire were weakly related to site-level climate and dominant subspecies (Table 3). Median annual establishment, CV of annual establishment, and the proportion of years with establishment were not significantly related to any tested climatic variables or to residual A. tridentata density, but the relatively large contribution of the random intercept terms indicated an important role of site characteristics that were not represented by climatic variables included in the models. Maximum annual post-fire establishment, which represented the magnitude of the largest establishment pulse, was greater in sites with higher annual precipitation $(\beta=1.50 ; 95 \% \mathrm{Cl}=1.01$ 2.23; Table 3). Neither mean climate, subspecies, residual $A$. tridentata density, nor site random effect explained much variation in maximum establishment density (conditional $R^{2}=0.12$ [climate model] and 0.07 [subspecies model]), indicating high variability within and among sites. Plots with A. t. ssp. tridentata had significantly lower median establishment, higher establishment CV, and a lower proportion of establishment years than other subspecies (Table 3). This subspecies occurred at only two plots at one site (Bridge Creek) and had median establishment densities of 0 (see Figure S1). 

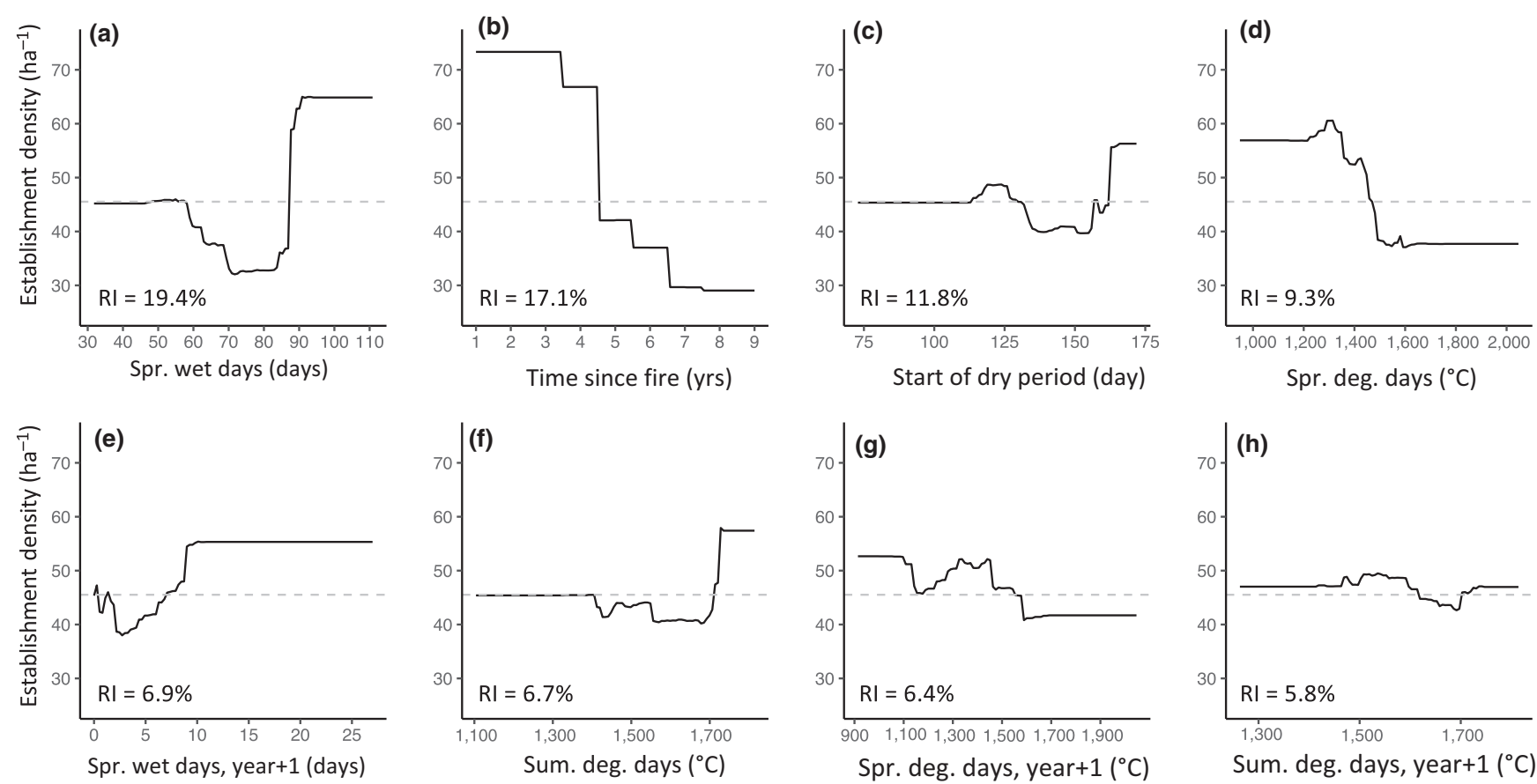
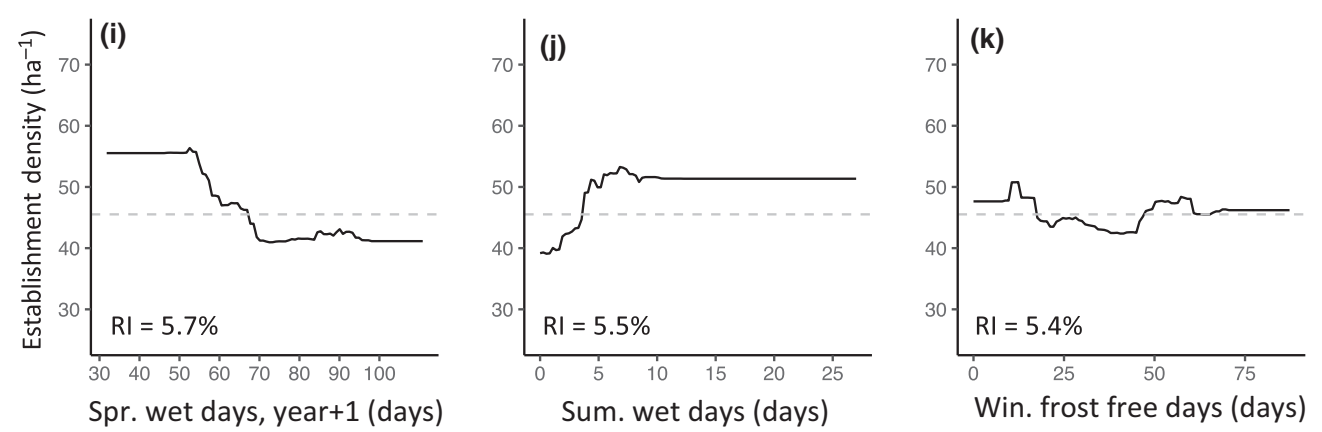

FIGURE 2 Partial dependency plots for variables in a boosted regression tree predicting annual A. tridentata establishment density $\left(\mathrm{ha}^{-1}\right)$. Each panel $(\mathrm{a}-\mathrm{k})$ shows the relationship between establishment density and a single predictor variable, ordered by decreasing relative influence (RI). Partial dependency plots (black solid lines) represent the estimated marginal effect of a variable on the response when all other variables are held at their average. Grey dashed lines indicate median establishment density across all plots and years. Predictor variables represent conditions in the year of establishment, except for those named 'year +1 ', which represent conditions in the year following establishment (i.e. conditions experienced by a 1-year-old plant)

\section{3 | Importance of temporal patterns of post-fire establishment for long-term population recovery}

Total post-fire A. tridentata density and cover were most strongly predicted by the magnitude of the largest post-fire establishment year (maximum annual establishment; Table 4; Figure 3). Density was predicted to be approximately four times greater in plots with the highest maximum annual establishment ( $\beta=219.9$; $95 \% \mathrm{Cl}=167.2-$ 280.4; Figure 3a). Density was also positively related to median annual establishment ( $\beta=212.0 ; 95 \% \mathrm{Cl}=150.0-275.3$ ). Cover was predicted to more than double with a 1-SD increase of maximum establishment (odds ratio; $\beta=2.17 ; 95 \% \mathrm{Cl}=1.55-3.15$; Figure $3 \mathrm{~b}$ ). Contrary to expectations, the frequency of post-fire establishment (proportion of years with establishment) was not associated with A. tridentata density $(\beta=-53.7 ; 95 \% \mathrm{Cl}=-128.4-10.2)$ or cover ( $\beta=0.77 ; 95 \% \mathrm{Cl}=0.46-1.29)$. Time since fire was positively related to $\operatorname{cover}(\beta=1.46 ; 95 \% \mathrm{Cl}=1.02-2.10)$, but was not predictive of post-fire density ( $\beta=3.8 ; 95 \% \mathrm{Cl}=-48.4-64.5)$. Residual $A$. tridentata density had a positive effect on $A$. tridentata cover $(\beta=2.18$; $95 \% \mathrm{Cl}=1.52-3.19$ ) but was not predictive of total post-fire density ( $\beta=44.8 ; 95 \% \mathrm{Cl}=-7.5-97.4)$. Total post-fire density did not differ among dominant $A$. tridentata subspecies (Figure $3 c$ ), but plots with A. t. vaseyana had higher cover than plots with A. t. wyomingensisafter accounting for covariate effects (Figure $3 \mathrm{~d}$ ). Temporal patterns of post-fire establishment were more predictive of density (marginal $R^{2}=0.91$ ) than of cover (marginal $R^{2}=0.70$; Table 4).

\section{4 | DISCUSSION}

Our results highlight the importance of infrequent periods of favourable conditions for determining recruitment and long-term plant population dynamics following disturbance. Post-fire $A$. tridentata recruitment was driven by episodic availability of spring soil moisture, 
TAB LE 3 Results from alternative models predicting plot-level establishment metrics in the first 8 years after fire as a function of climate normals (climate model) or dominant subspecies of Artemisia tridentata (subspecies model). Site was included as a random intercept. Shown are estimated regression coefficients $(\beta)$, with $95 \%$ confidence intervals $(\mathrm{Cl})$ calculated from parametric bootstrapping listed parenthetically. Continuous fixed effects bolded if $95 \% \mathrm{Cl}$ did not overlap 1 (models of median, maximum and $\mathrm{CV}$ establishment density) or did not overlap 0 (model of proportion of establishment years)



${ }^{a}$ Continuous predictor variables have been standardized.

${ }^{b}$ For continuous predictors of $\log _{10}$-transformed response variables, coefficient estimates are back-transformed and presented as odds ratios such that each increase in the predictor variable by $1 S D$ multiplies the expected value of the response by $\beta$.

${ }^{\mathrm{c}}$ Absolute factor estimates provided for $A$. tridentata subspp. categories.

and population recovery was associated with the magnitude, but not frequency, of post-fire establishment pulses. Temporal patterns of establishment were poorly predicted by site-level climate or dominant subspecies.

\section{1 | Post-fire recruitment driven by episodic availability of spring soil moisture}

Spring soil water availability is a primary driver of perennial plant establishment in cold desert ecosystems that experience winterdominated precipitation followed by a gradual decline in soil moisture (Hardegree et al., 2016; James et al., 2019). Specifically, for A. tridentata, episodic establishment was promoted by wetter and cooler spring soil conditions and a later start of the seasonal drydown in the year of establishment. Although warmer temperatures can promote germination (Cline, Roundy, \& Christensen, 2018) and increase seedling biomass accumulation (Schlaepfer et al., 2014), we found that recruitment was associated with cooler spring temperatures. Decreased plant community transpiration resulting from cooler temperatures may prolong onset of soil water stress during the seasonal dry-down process, and mean annual temperature was found to be more important than precipitation in rangewide models of $A$. tridentata dynamics (Kleinhesselink \& Adler, 2018; Renwick et al., 2018). Freeze-thaw cycles may constrain survival of early-germinating seedlings (Roundy \& Madsen, 2016), but we observed no influence of winter frost-free days on establishment. Effects of soil environmental conditions beyond the year of seedling establishment were negligible, indicating that first-year seedling survival is limited by harsh abiotic conditions and is the primary bottleneck to $A$. tridentata recruitment. However, we were not able to quantify the effect of extreme climatic events, which have the potential to cause ecological impacts such as widespread mortality across age classes (Miriti et al., 2007; Petrie et al., 2020).

Fires typically produce resource pulses that result in short establishment windows before resources are used by competing residual and newly established plants (Jentsch \& White, 2019). We found a 4-5-year window for post-fire $A$. tridentata 
TABLE 4 Results from models predicting total post-fire Artemisia tridentata density and cover as a function of plot-level temporal patterns of establishment. Site was included as a random intercept. Shown are estimated regression coefficients $(\beta)$, with $95 \%$ confidence intervals $(\mathrm{Cl})$ calculated from parametric bootstrapping listed parenthetically. Fixed effects bolded where $95 \% \mathrm{Cl}$ did not overlap 0 (density model) or did not overlap 1 (cover model)

FIGURE 3 Partial effect plots for models predicting post-fire Artemisia tridentata density $(a, c)$ and cover (b, d). Marginal effect of maximum annual establishment on post-fire $A$. tridentata (a) density $(\beta[95 \% \mathrm{Cl}]=209.1$ [147.4-267.7]) and (b) cover $\left(\log _{10} ; \beta[95 \% \mathrm{Cl}]=2.40\right.$ [1.48-4.07]). Marginal estimates of postfire (c) density and (d) cover by subspecies. Lines represent the coefficient mean estimate $\pm 95 \%$ confidence interval. Sampling occurred between 8 and 11 years after fire, and both density and cover models included time since fire and residual $A$. tridentata density as covariates, with a random intercept for site

\begin{tabular}{|c|c|c|}
\hline & $\begin{array}{l}\text { Post-fire A. tridentata density } \\
\left(\mathrm{ha}^{-1}\right)\end{array}$ & $\begin{array}{l}\text { A. tridentata cover } \\
\left(\% ; \log _{10}\right)^{a}\end{array}$ \\
\hline Predictor & $\beta(95 \% \mathrm{Cl})$ & \\
\hline Median annual establishment ${ }^{b}$ & $212.0(150.0-275.3)$ & $1.39(0.90-2.02)$ \\
\hline Maximum annual establishment ${ }^{b}$ & $219.9(167.3-280.4)$ & $2.17(1.55-3.15)$ \\
\hline Proportion of establishment $y r s^{b}$ & $-53.7(-128.4-10.2)$ & $0.77(0.46-1.29)$ \\
\hline Yrs since fire ${ }^{b}$ & $3.8(-48.4-64.5)$ & $1.46(1.02-2.10)$ \\
\hline Residual A. tridentata ${ }^{b}$ & $44.8(-7.5-97.4)$ & $2.18(1.52-3.19)$ \\
\hline A. tridentata ssp. Tridentata ${ }^{c}$ & $378.3(131.1-630.0)$ & $0.76(0.15-4.02)$ \\
\hline A. tridentata ssp. Wyomingensis ${ }^{c}$ & $543.7(465.5-628.3)$ & $1.03(0.59-1.66)$ \\
\hline A. tridentata ssp. Vaseyana ${ }^{c}$ & $599.4(508.9-679.1)$ & $5.10(2.91-8.57)$ \\
\hline Marginal $R^{2}$ & 0.91 & 0.70 \\
\hline Conditional $R^{2}$ & 0.92 & 0.71 \\
\hline
\end{tabular}

${ }^{a}$ Coefficient estimates are back-transformed from the $\log _{10}$ scale. For continuous predictor variables, each one-unit increase in the predictor variable multiplies the expected value of the response by $\beta$.

${ }^{b}$ Continuous predictor variables have been standardized, and regression coefficients give the effect of a change of 1 SD.

${ }^{\mathrm{C}}$ Absolute factor estimates provided for A. tridentata subspp. categories.

(a)

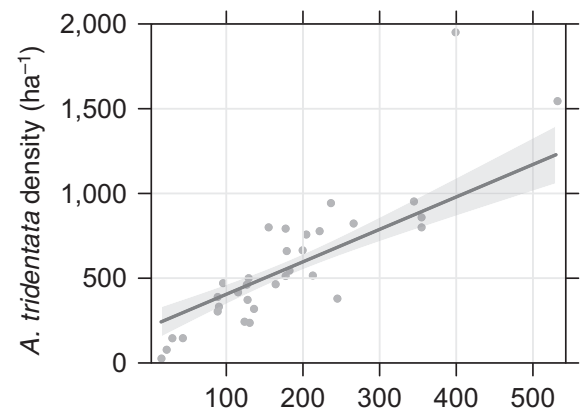

Maximum annual establishment $\left(\mathrm{ha}^{-1}\right)$

(c)

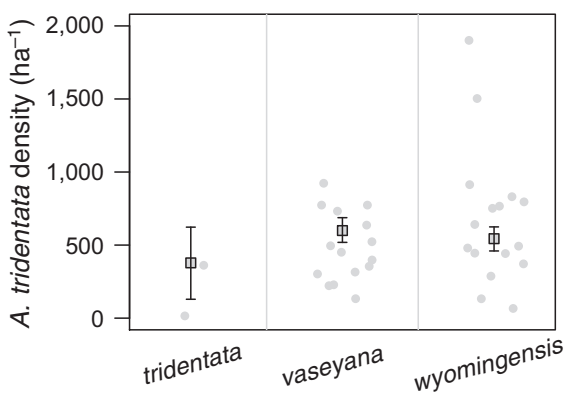

A. tridentata subspecies (b)

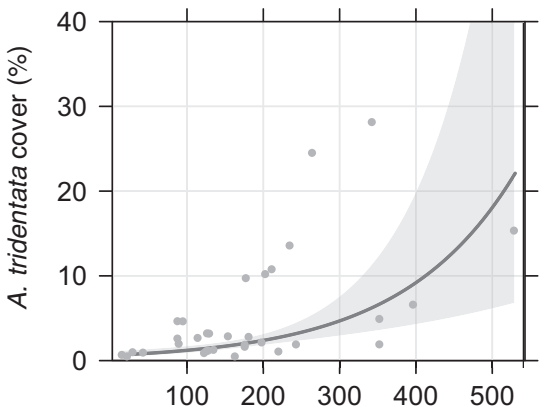

Maximum annual establishment $\left(\mathrm{ha}^{-1}\right)$

(d)

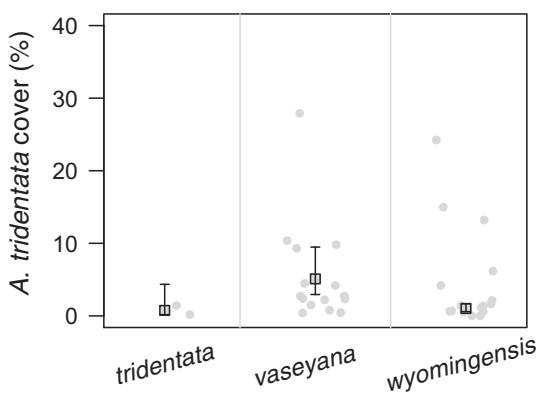

A. tridentata subspecies establishment, after which recruitment may have been limited by competition from other species that were increasing in abundance (Freund et al., 2021). This observed window of establishment is longer than previously suggested (Wijayratne \& Pyke, 2012; Ziegenhagen \& Miller, 2009). Most sampling plots contained residual $A$. tridentata individuals that had established prior to burning and survived the fire, and although the abundance of residual $A$. tridentata was not a significant predictor of establishment metrics, these surviving plants likely provided an important seed source throughout the post-fire period (Turner et al., 1998). Patchy burns are common for prescribed fires, which typically burn under conservative weather windows. Our study sites had heterogeneous tree, shrub and herbaceous cover (Chambers et al., 2014; Urza et al., 2017) and thus discontinuous 
fuel loadings that likely limited fire spread. In higher-severity burns with no surviving adult $A$. tridentata, the window of establishment is likely narrowed to 1 or 2 years after fire before depletion of viable seeds in the soil seedbank (Wijayratne \& Pyke, 2012). The observation of a 4-5-year window for establishment suggests that residual $A$. tridentata provided a continuous post-fire seed source that, compared to the soil seedbank alone, extended the opportunity for post-fire recruitment. Our findings underscore the importance of disturbance refugia-locations that experience less severe disturbance than the surrounding landscape, such as unburned patches-for contributing to postdisturbance recovery (Krawchuk et al., 2020).

Interannual variability may strongly influence ecosystem responses to climate change (Werner et al., 2020). Climate projections indicate declining snowpack, warming temperatures and increased variability in soil water availability in cold deserts of the western U.S. (Klos et al., 2014; Palmquist et al., 2016; Schlaepfer et al., 2012). Multiple modelling studies predict climate-induced reductions in $A$. tridentata recruitment, with the greatest losses in drier locations (Renwick et al., 2018; Schlaepfer et al., 2015). Our sites did not include the driest $A$. tridentata habitats. However, we found that both the magnitude (median and maximum) and variability (CV and frequency) of establishment were poorly predicted by mean climatic conditions, and that even typically dry sites experienced large pulses of establishment. Thus, interannual variability in climate may help buffer recruitment dynamics against short-term effects of climate change, as long as there is reasonable probability of favourable conditions during the post-fire window for establishment. For example, interannual variability in precipitation has been shown to increase the resilience of Iberian semi-arid plant communities to changing rainfall patterns (Miranda et al., 2011).

\section{2 | Post-fire population recovery reflects the magnitude, but not frequency, of early establishment pulses}

Post-disturbance community recovery is sensitive to both the magnitude and frequency of episodic establishment events (Chesson et al., 2004). While population recovery may be driven by single establishment events, population dynamics of perennial plants tend to reflect the cumulative effects of multiple pulses occurring over time (Chesson et al., 2004). Contrary to our expectations, total post-fire A. tridentata density, which represents the size of the population that established after fire, was well predicted by the magnitude of the largest establishment pulse but was not related to the frequency of establishment events. The lack of a relationship between postfire density and time since fire (8-11 years after fire) means that the population size did not change over that time period and suggests that demographic processes such as recruitment and mortality had largely stabilized by the time of sampling. Canopy cover, which represents sagebrush habitat, was less strongly related to post-fire establishment pulses, although A. tridentata cover was higher in sites with a larger peak of maximum annual establishment. Cover was also positively associated with time since fire, which, given the finding of a consistent population size over time, likely reflects age-related plant growth rather than recruitment. Residual A. tridentata density was positively related to cover; however, because cover measurements included both pre-fire and post-fire individuals, we cannot infer whether the effect is due to an influence on seed availability or simply because the surviving plants comprised a substantial amount of canopy cover.

The strong relationship between post-fire density and maximum annual establishment suggests that population recovery is possible with a single favourable year within the 4-5-year post-fire establishment window. However, we did not explore potentially important effects of post-fire recruitment frequency on population and habitat structure. For example, A. tridentata recruitment pulses are often followed by steep population declines because seedlings have low survival probabilities, and early post-fire stands are susceptible to extirpation (Chambers et al., 2017; Shriver et al., 2019). Multiple establishment episodes may buffer the risk of population loss by increasing the probability that seedling cohorts will survive subsequent conditions. To better understand post-fire population recovery, research is needed on how specific demographic processes-including seed production, seedling mortality and growth-respond individually to interannual weather and interactions with neighbouring plants (Chesson et al., 2004).

\subsection{Management implications}

Our results suggest opportunities for improving management outcomes and promoting conservation of ecosystems losing foundation species due to altered fire regimes. In the western U.S., the Bureau of Land Management seeded thousands of $\mathrm{km}^{2}$ with A. tridentata after fires during recent decades (Pilliod et al., 2017). Although seeding can successfully promote post-fire A. tridentata recovery in some circumstances (Germino et al., 2018; Ott et al., 2017; Urza et al., 2019), outcomes of landscape-scale seeding treatments are often poor (Knutson et al., 2014). A better understanding of the factors determining establishment of obligate seeders, like sagebrush, can be used to effectively prioritize resources for restoration of disturbed landscapes.

Our study showed that a residual seed source can promote establishment of an obligate seeder during years with favourable weather conditions for up to 5 years after fire. Artemisia tridentata seeds have a short period of viability and are not likely to survive fire (Wijayratne \& Pyke, 2012), and residual, seed-producing individuals are critical to continuous post-fire seed availability. Thus, recovery may be improved by fire management strategies that leave fine-scale mosaics of unburned patches, within incomplete-burn prescribed fires and throughout fire interiors during wildfire suppression operations.

Our results also suggest that the window of opportunity for post-fire seeding in the interior of larger fires may be longer 
than previously thought. In drier portions of the landscape, restoration treatments can be timed so seed availability coincides with favourable weather and results in successful establishment. Seasonal weather forecasts are becoming more available (Bradford et al., 2018; Hardegree et al., 2018) and can help ensure seeding is implemented in years when favourable conditions (e.g. wet, cool springs) will promote establishment. Additionally, repeated seeding in multiple successive years may improve restoration success in high-priority areas by increasing the odds that seed availability coincides with favourable conditions for establishment (Davies et al., 2018; Shriver et al., 2018; Wilson et al., 2004). Planned repeated seeding may decrease market uncertainties for the seed industry and enable increases in availability of locally-adapted seed sources when coupled with proper seed storage (Brabec et al., 2015). A stable seed market would also help alleviate the current temporal mismatch of available commercial seed sources and large fire years when post-fire restoration needs are high (Camhi et al., 2019). Our study contributes to the growing body of evidence that infrequent periods of soil water availability are a major driver of post-disturbance recovery and highlights the importance of developing management strategies grounded in the underlying ecology of foundation plant species.

\section{ACKNOWLEDGEMENTS}

This work was supported by a US Joint Fire Science Program Graduate Research Innovation award (JFSP Project ID: 16-2-01-27) and the USDA Forest Service, Rocky Mountain Research Station. We thank Matt Church and Jake Barrett for field data collection; Stephanie Carlson for annual growth-ring laboratory work; and the Nevada Agricultural Experiment Station for logistical support. We are grateful to Jim Mclver and the SageSTEP project team for permitting and facilitating this research. The findings and conclusions in this publication are those of the authors and should not be considered to represent any official USDA or U.S. Government determination or policy.

\section{AUTHORS' CONTRIBUTIONS}

A.K.U., P.J.W., J.C.C. and S.G.K. conceived the ideas and designed the methodology; A.K.U., P.J.W., D.B., S.G.K. and B.A.R. collected the data; D.B. and A.K.U. analysed the data; A.K.U. led the writing of the manuscript. All authors contributed critically to the drafts and gave final approval for publication.

\section{DATA AVAILABILITY STATEMENT}

Data available via the Dryad Digital Repository https://doi.org/ 10.5061/dryad.jh9w0vtbk (Urza et al., 2021).

\section{ORCID}

Alexandra K. Urza iD https://orcid.org/0000-0001-9795-6735

David Board (iD https://orcid.org/0000-0001-6140-1260

Jeanne C. Chambers iD https://orcid.org/0000-0003-3111-269X

Stanley G. Kitchen iD https://orcid.org/0000-0002-5536-4237

Bruce A. Roundy iD https://orcid.org/0000-0003-2544-5324

\section{REFERENCES}

Arkle, R. S., Pilliod, D. S., Hanser, S. E., Brooks, M. L., Chambers, J. C., Grace, J. B., Knutson, K. C., Pyke, D. A., Welty, J. L., \& Wirth, T. A. (2014). Quantifying restoration effectiveness using multi-scale habitat models: Implications for sage-grouse in the Great Basin. Ecosphere, 5, 1-32. https://doi.org/10.1890/ES13-00278.1

Arnan, X., Rodrigo, A., \& Retana, J. (2007). Post-fire regeneration of Mediterranean plant communities at a regional scale is dependent on vegetation type and dryness. Journal of Vegetation Science, 18, 111122. https://doi.org/10.1111/j.1654-1103.2007.tb02521.x

Barton, K. (2015). MuMIn: Multi-model inference. R package version 1.15.1. Retrieved from https://cran.r-project.org/web/packages/ MuMIn/

Bates, D., Maechler, M., Bolker, B., \& Walker, S. (2015). Ime4: Linear mixed-effects models using 'Eigen' and S4. R package version 1.1-10. Retrieved from https://cran.r-project.org/web/packages/Ime4/

Brabec, M. M., Germino, M. J., Shinneman, D. J., Pilliod, D. S., Mcllroy, S. K., \& Arkle, R. S. (2015). Challenges of establishing big sagebrush (Artemisia tridentata) in rangeland restoration: Effects of herbicide, mowing, whole-community seeding, and sagebrush seed sources. Rangeland Ecology and Management, 68, 432-435. https://doi. org/10.1016/j.rama.2015.07.001

Bradford, J. B., Betancourt, J. L., Butterfield, B. J., Munson, S. M., \& Wood, T. E. (2018). Anticipatory natural resource science and management for a changing future. Frontiers in Ecology and the Environment, 16, 295-303. https://doi.org/10.1002/fee.1806

Bradley, B. A., Curtis, C. A., Fusco, E. J., Abatzoglou, J. T., Balch, J. K., Dadashi, S., \& Tuanmu, M. N. (2018). Cheatgrass (Bromus tectorum) distribution in the intermountain Western United States and its relationship to fire frequency, seasonality, and ignitions. Biological Invasions, 20, 1493-1506. https://doi.org/10.1007/s1053 0-017-1641-8

Brooks, M. L., D’Antonio, C. M., Richardson, D. M., Grace, J. B., Keeley, J. E., DiTomaso, J. M., Hobbs, R. J., Pellant, M., \& Pyke, D. (2004). Effects of invasive alien plants on fire regimes. BioScience, 54(7), 677688. https://doi.org/10.1641/0006-3568(2004)054[0677:EOIAP O]2.0.CO;2

Brown, J. H., Whitham, T. G., Ernest, S. K. M., \& Gehring, C. A. (2001). Complex species interactions and the dynamics of ecological systems: Long-term experiments. Science, 293, 643-651. https://doi. org $/ 10.1126 /$ science.293.5530.643

Camhi, A. L., Perrings, C., Butterfield, B., \& Wood, T. (2019). Marketbased opportunities for expanding native seed resources for restoration: A case study on the Colorado Plateau. Journal of Environmental Management, 252, 109644. https://doi.org/10.1016/j. jenvman.2019.109644

Chambers, J. C., Board, D. I., Roundy, B. A., \& Weisberg, P. J. (2017). Removal of perennial herbaceous species affects response of Cold Desert shrublands to fire. Journal of Vegetation Science, 28, 975-984. https://doi.org/10.1111/jvs.12548

Chambers, J. C., Miller, R. F., Board, D. I., Pyke, D. A., Roundy, B. A., Grace, J. B., Schupp, E. W., \& Tausch, R. J. (2014). Resilience and resistance of sagebrush ecosystems: Implications for state and transition models and management treatments. Rangeland Ecology and Management, 67, 440-454. https://doi.org/10.2111/ REM-D-13-00074.1

Chambers, J. C., Roundy, B. A., Blank, R. R., Meyer, S. E., \& Whittaker, A. (2007). What makes Great Basin sagebrush ecosystems invasible by Bromus tectorum? Ecological Monographs, 77, 117-145. https://doi. org/10.1890/05-1991

Chesson, P., Gebauer, R. L. E., Schwinning, S., Huntly, N., Wiegand, K., Ernest, M. S. K., Sher, A., Novoplansky, A., \& Weltzin, J. F. (2004). Resource pulses, species interactions, and diversity maintenance in arid and semi-arid environments. Oecologia, 141, 236-253. https:// doi.org/10.1007/s00442-004-1551-1 
Christopoulou, A., Fyllas, N. M., Andriopoulos, P., Koutsias, N., Dimitrakopoulos, P. G., \& Arianoutsou, M. (2014). Post-fire regeneration patterns of Pinus nigra in a recently burned area in Mount Taygetos, Southern Greece: The role of unburned forest patches. Forest Ecology and Management, 327, 148-156. https://doi. org/10.1016/j.foreco.2014.05.006

Cline, N. L., Roundy, B. A., \& Christensen, W. F. (2018). Using germination prediction to inform seeding potential: I. temperature range validation of germination prediction models for the Great Basin, USA. Journal of Arid Environments, 150, 71-81. https://doi.org/10.1016/j. jaridenv.2017.11.018

Cline, N. L., Roundy, B. A., Hardegree, S., \& Christensen, W. (2018). Using germination prediction to inform seeding potential: II. comparison of germination predictions for cheatgrass and potential revegetation species in the Great Basin, USA. Journal of Arid Environments, 150, 82-91. https://doi.org/10.1016/j.jaridenv.2017.11.019

Coates, P. S., Ricca, M. A., Prochazka, B. G., Brooks, M. L., Doherty, K. E., Kroger, T., Blomberg, E. J., Hagen, C. A., \& Casazza, M. L. (2016). Wildfire, climate, and invasive grass interactions negatively impact an indicator species by reshaping sagebrush ecosystems. Proceedings of the National Academy of Sciences of the United States of America, 113, 12747-12750. https://doi.org/10.1073/ pnas. 1606898113

Davies, K. W., Boyd, C. S., Beck, J. L., Bates, J. D., Svejcar, T. J., \& Gregg, M. A. (2011). Saving the sagebrush sea: An ecosystem conservation plan for big sagebrush plant communities. Biological Conservation 144, 2573-2584. https://doi.org/10.1016/j.biocon.2011.07.016

Davies, K. W., Boyd, C. S., Madsen, M. D., Kerby, J., \& Hulet, A. (2018). Evaluating a seed technology for sagebrush restoration across an elevation gradient: Support for bet hedging. Rangeland Ecology and Management, 71, 19-24. https://doi.org/10.1016/j. rama.2017.07.006

de Elía, R., Biner, S., \& Frigon, A. (2013). Interannual variability and expected regional climate change over North America. Climate Dynamics, 41, 1245-1267. https://doi.org/10.1007/s00382-013-1717-9

Dilts, T. E., Weisberg, P. J., Dencker, C. M., \& Chambers, J. C. (2015). Functionally relevant climate variables for arid lands: A climatic water deficit approach for modelling desert shrub distributions. Journal of Biogeography, 42, 1986-1997. https://doi.org/10.1111/jbi.12561

Elith, J., Leathwick, J. R., \& Hastie, T. J. (2008). A working guide to boosted regression trees. Journal of Animal Ecology, 77, 802-813. https://doi. org/10.1111/j.1365-2656.2008.01390.x

Freund, S. M., Newingham, B. A., Chambers, J. C., Urza, A. K., Roundy, B. A., \& Cushman, J. H. (2021). Plant functional groups and species contribute to ecological resilience a decade after woodland expansion treatments. Ecosphere, 12, e03325. https://doi.org/10.1002/ ecs2.3325

Fusco, E. J., Finn, J. T., Balch, J. K., Chelsea Nagy, R., \& Bradley, B. A. (2019). Invasive grasses increase fire occurrence and frequency across US ecoregions. Proceedings of the National Academy of Sciences of the United States of America, 116, 23594-23599. https://doi. org/10.1073/pnas.1908253116

Germino, M. J., Barnard, D. M., Davidson, B. E., Arkle, R. S., Pilliod, D. S., Fisk, M. R., \& Applestein, C. (2018). Thresholds and hotspots for shrub restoration following a heterogeneous megafire. Landscape Ecology, 33, 1177-1194. https://doi.org/10.1007/s10980-018-0662-8

Greenwell, B., Boehmke, B., Cunningham, J., \& Developers, G. B. M. (2019). gbm: Generalized boosted regression models. R package version 2.1.5. Retrieved from https://cran.r-project.org/web/packages/gbm/

Hardegree, S. P., Abatzoglou, J. T., Brunson, M. W., Germino, M. J., Hegewisch, K. C., Moffet, C. A., Pilliod, D. S., Roundy, B. A., Boehm, A. R., \& Meredith, G. R. (2018). Weather-centric rangeland revegetation planning. Rangeland Ecology and Management, 71, 1-11. https:// doi.org/10.1016/j.rama.2017.07.003
Hardegree, S. P., Sheley, R. L., Duke, S. E., James, J. J., Boehm, A. R., \& Flerchinger, G. N. (2016). Temporal variability in microclimatic conditions for grass germination and emergence in the sagebrush steppe. Rangeland Ecology and Management, 69, 123-128. https://doi. org/10.1016/j.rama.2015.12.002

Herrick, J. E., Van Zee, J. W., McCord, S. E., Courtright, E. M., Karl, J. W., \& Burkett, L. M. (2017). Monitoring manual for grassland, shrubland and savanna ecosystems (Volume I: Quick Start. 2nd ed.). USDA-ARS Jornada Experimental Range.

Hijmans, R. J., Phillips, S., Leathwick, J., \& Elith, J. (2017). dismo: Species distribution modeling. R package version 1.1-4. Retrieved from cran.rproject.org/web/packages/dismo/

James, J. J., Sheley, R. L., Leger, E. A., Adler, P. B., Hardegree, S. P., Gornish, E. S., \& Rinella, M. J. (2019). Increased soil temperature and decreased precipitation during early life stages constrain grass seedling recruitment in cold desert restoration. Journal of Applied Ecology, 56, 2609-2619. https://doi.org/10.1111/1365-2664. 13508

Jentsch, A., \& White, P. (2019). A theory of pulse dynamics and disturbance in ecology. Ecology, 100, 1-15. https://doi.org/10.1002/ ecy. 2734

Johnstone, J. F., Hollingsworth, T. N., Chapin, F. S., \& Mack, M. C. (2010). Changes in fire regime break the legacy lock on successional trajectories in Alaskan boreal forest. Global Change Biology, 16, 1281-1295. https://doi.org/10.1111/j.1365-2486.2009.02051.x

Kleinhesselink, A. R., \& Adler, P. B. (2018). The response of big sagebrush (Artemisia tridentata) to interannual climate variation changes across its range. Ecology, 99(5), 1139-1149. https://doi.org/10.1002/ ecy. 2191

Klos, P. Z., Link, T. E., \& Abatzoglou, J. T. (2014). Extent of the rain-snow transition zone in the western U.S. under historic and projected climae. Geophysical Research Letters, 41, 6413-6419. https://doi. org/10.1002/2014GL060500

Knutson, K. C., Pyke, D. A., Wirth, T. A., Arkle, R. S., Pilliod, D. S., Brooks, M. L., Chambers, J. C., \& Grace, J. B. (2014). Long-term effects of seeding after wildfire on vegetation in Great Basin shrubland ecosystems. Journal of Applied Ecology, 51, 1414-1424. https://doi. org/10.1111/1365-2664.12309

Krawchuk, M. A., Meigs, G. W., Cartwright, J. M., Coop, J. D., Davis, R., Holz, A., Kolden, C., \& Meddens, A. J. H. (2020). Disturbance refugia within mosaics of forest fire, drought, and insect outbreaks. Frontiers in Ecology and the Environment, 18, 235-244. https://doi. org/10.1002/fee. 2190

Loik, M. E., Breshears, D. D., Lauenroth, W. K., \& Belnap, J. (2004). A multi-scale perspective of water pulses in dryland ecosystems: Climatology and ecohydrology of the western USA. Oecologia, 141, 269-281. https://doi.org/10.1007/s00442-004-1570-y

Loughin, T. M. (2006). Improved experimental design and analysis for long-term experiments. Crop Science, 46, 2492-2502. https://doi. org/10.2135/cropsci2006.04.0271

Lutz, J. A., van Wagtendonk, J. W., \& Franklin, J. F. (2010). Climatic water deficit, tree species ranges, and climate change in Yosemite National Park. Journal of Biogeography, 37, 936-950. https://doi. org/10.1111/j.1365-2699.2009.02268.x

Maestre, F. T., Eldridge, D. J., Soliveres, S., Kéfi, S., Delgado-Baquerizo, M., Bowker, M. A., García-Palacios, P., Gaitán, J., Gallardo, A., Lázaro, R., \& Berdugo, M. (2016). Structure and functioning of dryland ecosystems in a changing world. Annual Review of Ecology, Evolution, and Systematics, 47, 215-237. https://doi.org/10.1146/annurev-ecolsys121415-032311

Malanson, G. P., Resler, L. M., \& Tomback, D. F. (2017). Ecotone response to climatic variability depends on stress gradient interactions. Climate Change Responses, 4, 1-8. https://doi.org/10.1186/s4066 5-017-0029-4 
Mclver, J., \& Brunson, M. (2014). Multidisciplinary, multisite evaluation of alternative sagebrush steppe restoration treatments: The SageSTEP Project. Rangeland Ecology and Management, 67, 435-439. https:// doi.org/10.2111/REM-D-14-00085.1

Miranda, J. D., Armas, C., Padilla, F. M., \& Pugnaire, F. I. (2011). Climatic change and rainfall patterns: Effects on semi-arid plant communities of the Iberian Southeast. Journal of Arid Environments, 75, 13021309. https://doi.org/10.1016/j.jaridenv.2011.04.022

Miranda, J. D. D., Padilla, F. M., Lázaro, R., \& Pugnaire, F. I. (2009). Do changes in rainfall patterns affect semiarid annual plant communities? Journal of Vegetation Science, 20, 269-276. https://doi. org/10.1111/j.1654-1103.2009.05680.x

Miriti, M. N., Rodríguez-Buriticá, S., Wright, S. J., \& Howe, H. F. (2007). Episodic death across species of desert shrubs. Ecology, 88, 32-36.

Nelson, Z. J., Weisberg, P. J., \& Kitchen, S. G. (2014). Influence of climate and environment on post-fire recovery of mountain big sagebrush. International Journal of Wildland Fire, 23, 131-142. https://doi. org/10.1071/WF13012

Ott, J. E., Cox, R. D., \& Shaw, N. L. (2017). Comparison of postfire seeding practices for Wyoming big sagebrush. Rangeland Ecology and Management, 70, 625-632. https://doi.org/10.1016/j. rama.2017.03.005

Palmquist, K. A., Schlaepfer, D. R., Bradford, J. B., \& Lauenroth, W. K. (2016). Mid-latitude shrub steppe plant communities: Climate change consequences for soil water resources. Ecology, 97, 2342-2354. https://doi.org/10.1002/ecy.1457

Petrie, M. D., Bradford, J. B., Hubbard, R. M., Lauenroth, W. K., Andrews, C. M., \& Schlaepfer, D. R. (2017). Climate change may restrict dryland forest regeneration in the 21st century. Ecology, 98, 1548-1559. https://doi.org/10.1002/ecy.1791

Petrie, M. D., Bradford, J. B., Lauenroth, W. K., Schlaepfer, D. R., Andrews, C. M., \& Bell, D. M. (2020). Non-analog increases to air, surface, and belowground temperature extreme events due to climate change. Climatic Change, 163, 2233-2256. https://doi.org/10.1007/s10584020-02944-7

Pilliod, D. S., Welty, J. L., \& Toevs, G. R. (2017). Seventy-five years of vegetation treatments on public rangelands in the Great Basin of North America. Rangelands, 39, 1-9. https://doi.org/10.1016/j. rala.2016.12.001

PRISM Climate Group. (2016). PRISM Gridded Climate Data. Retrieved from http://prism.oregonstate.edu

R Core Team. (2018). R: A language and environment for statistical computing. R Foundation for Statistical Computing. Retrieved from https:// cran.r-project.org

Redmond, M. D., Forcella, F., \& Barger, N. N. (2012). Declines in pinyon pine cone production associated with regional warming. Ecosphere, 3(12), art120. https://doi.org/10.1890/ES12-00306.1

Redmond, M. D., Kelsey, K. C., Urza, A. K., \& Barger, N. N. (2017). Interacting effects of climate and landscape physiography on piñon pine growth using an individual-based approach. Ecosphere, 8, e01681. https://doi.org/10.1002/ecs2.1681

Renwick, K. M., Curtis, C., Kleinhesselink, A. R., Schlaepfer, D., Bradley B. A., Aldridge, C. L., Poulter, B., \& Adler, P. B. (2018). Multi-model comparison highlights consistency in predicted effect of warming on a semi-arid shrub. Global Change Biology, 24, 424-438. https://doi. org/10.1111/gcb.13900

Roundy, B. A., Chambers, J. C., Pyke, D. A., Miller, R. F., Tausch, R. J., Schupp, E. W., Rau, B., \& Gruell, T. (2018). Resilience and resistance in sagebrush ecosystems are associated with seasonal soil temperature and water availability. Ecosphere, 9. https://doi.org/10.1002/ ecs2.2417

Roundy, B. A., \& Madsen, M. D. (2016). Frost dynamics of sagebrush steppe soils. Soil Science Society of America Journal, 80, 1403-1410. https://doi.org/10.2136/sssaj2016.03.0087
Roundy, B. A., Miller, R. F., Tausch, R. J., Chambers, J. C., \& Rau, B. M. (2020). Long-term effects of tree expansion and reduction on soil climate in a semiarid ecosystem. Ecosphere, 11, e03241. https://doi. org/10.1002/ecs2.3241

Roundy, B. A., Young, K., Cline, N., Hulet, A., Miller, R. F., Tausch, R. J., Chambers, J. C., \& Rau, B. (2014). Piñon-juniper reduction effects on soil temperature and water availability of the resource growth pool. Rangeland Ecology \& Management, 67, 495-505.

Schlaepfer, D. R., Lauenroth, W. K., \& Bradford, J. B. (2012). Consequences of declining snow accumulation for water balance of mid-latitude dry regions. Global Change Biology, 18, 1988-1997. https://doi. org/10.1111/j.1365-2486.2012.02642.x

Schlaepfer, D. R., Lauenroth, W. K., \& Bradford, J. B. (2014). Natural regeneration processes in big sagebrush (Artemisia tridentata). Rangeland Ecology \& Management, 67, 344-357. https://doi.org/10.2111/ REM-D-13-00079.1

Schlaepfer, D. R., Taylor, K. A., Pennington, V. E., Nelson, K. N., Martyn, T. E., Rottler, C. M., Lauenroth, W. K., \& Bradford, J. B. (2015). Simulated big sagebrush regeneration supports predicted changes at the trailing and leading edges of distribution shifts. Ecosphere, 6, 131. https://doi.org/10.1890/ES14-00208.1

Schwinning, S., \& Sala, O. E. (2004). Hierarchy of responses to resource pulses in arid and semi-arid ecosystems. Oecologia, 141, 211-220. https://doi.org/10.1007/s00442-004-1520-8

Shriver, R. K., Andrews, C. M., Arkle, R. S., Barnard, D. M., Duniway, M. C., Germino, M. J., Pilliod, D. S., Pyke, D. A., Welty, J. L., \& Bradford, J. B. (2019). Transient population dynamics impede restoration and may promote ecosystem transformation after disturbance. Ecology Letters, 22(9), 1357-1366. https://doi.org/10.1111/ele.13291

Shriver, R. K., Andrews, C. M., Pilliod, D. S., Arkle, R. S., Welty, J. L., Germino, M. J., Duniway, M. C., Pyke, D. A., \& Bradford, J. B. (2018). Adapting management to a changing world: Warm temperatures, dry soil, and interannual variability limit restoration success of a dominant woody shrub in temperate drylands. Global Change Biology, 24, 4972-4982. https://doi.org/10.1111/gcb.14374

Shryock, D. F., Esque, T. C., \& Chen, F. C. (2015). Topography and climate are more important drivers of long-term, post-fire vegetation assembly than time-since-fire in the Sonoran Desert, US. Journal of Vegetation Science, 26, 1134-1147. https://doi.org/10.1111/ jvs.12324

Stokes, M. A., \& Smiley, T. L. (1968). An introduction to tree-ring dating. University of Chicago Press.

Turner, M. G., Baker, W. L., Peterson, C. J., \& Peet, R. K. (1998). Factors influencing succession: Lessons from large, infrequent natural disturbances. Ecosystems, 1, 511-523. https://doi.org/10.1007/s1002 19900047

Urza, A. K., Weisberg, P. J., Board, D., Chambers, J. C., Kitchen, S. G., \& Roundy, B. A. (2021). Data from: Episodic occurrence of favourable weather constrains recovery of a cold desert shrubland after fire. Dryad Digital Repository, https://doi.org/10.5061/dryad. jh9w0vtbk

Urza, A. K., Weisberg, P. J., Chambers, J. C., Board, D., \& Flake, S. W. (2019). Seeding native species increases resistance to annual grass invasion following prescribed burning of semiarid woodlands. Biological Invasions, 21, 1993-2007. https://doi.org/10.1007/s1053 0-019-01951-9

Urza, A. K., Weisberg, P. J., Chambers, J. C., Dhaemers, J. M., \& Board, D. (2017). Post-fire vegetation response at the woodland - shrubland interface is mediated by the pre-fire community. Ecosphere, 8 , e01851. https://doi.org/10.1002/ecs2.1851

Werner, C. M., Stuble, K. L., Groves, A. M., \& Young, T. P. (2020). Year effects: Interannual variation as a driver of community assembly dynamics. Ecology, 101(9), 1-8. https://doi.org/10.1002/ ecy.3104 
Wiegand, K., Jeltsch, F., \& Ward, D. (2004). Minimum recruitment frequency in plants with episodic recruitment. Oecologia, 141, 363-372. https://doi.org/10.1007/s00442-003-1439-5

Wijayratne, U. C., \& Pyke, D. A. (2012). Burial increases seed longevity of two Artemisia tridentata (Asteraceae) subspecies. American Journal of Botany, 99, 438-447. https://doi.org/10.3732/ajb.1000477

Wilson, S. D., Bakker, J. D., Christian, J. M., Xingdong, L. I., Ambrose, L. G., \& Waddington, J. (2004). Semiarid old-field restoration: Is neighbor control needed? Ecological Applications, 14, 476-484. https://doi. org/10.1890/02-5296

Ziegenhagen, L. L., \& Miller, R. F. (2009). Postfire recovery of two shrubs in the interiors of large burns in the Intermountain West, USA. Western North American Naturalist, 69, 195-205. https://doi. org/10.3398/064.069.0208

\section{SUPPORTING INFORMATION}

Additional supporting information may be found online in the Supporting Information section.

How to cite this article: Urza AK, Weisberg PJ, Board D, Chambers JC, Kitchen SG, Roundy BA. Episodic occurrence of favourable weather constrains recovery of a cold desert shrubland after fire. J Appl Ecol. 2021;00:1-14. https://doi. org/10.1111/1365-2664.13911 